\title{
PENINGKATAN KETERAMPILAN MENYIMAK KOMPREHENSIF DAN KRITIS DENGAN METODE RESITASI
}

\author{
Wiendi Wiranty \\ Program Studi Pendidikan Bahasa dan Sastra Indonesia \\ Fakultas Bahasa dan Seni IKIP PGRI Pontianak \\ Jalan Ampera Nomor 88 Pontianak - 78116 \\ e-mail: Wiendiwiranty88@gmail.com
}

\begin{abstract}
Abstrak
Penelitian dilakukan berdasarkan kesulitan mahasiswa akan keterampilan menyimak komprehensif dan kritis. Tujuan penelitian adalah untuk meningkatkan keterampilan menyimak komprehensif dan kritis menggunakan metode resitasi. Metode penelitian menggunakan classroom action research. Subjek penelitian adalah mahasiswa kelas A Sore semester 2 angkatan 2017. Teknik pengumpul data menggunakan komunikasi langsung, komunikasi tidak langsung, observasi, pengukuran, dan dokumentasi. Alat pengumpul data menggunakan pedoman wawancara, angket, panduan observasi, tes, dan dokumentasi. Teknik analisis data meggunakan teknik statistik deskriptif komparatif dan analisis kritis. Hasil penelitian menunjukkan terjadi peningkatan yang signifikan antara siklus pertama dan siklus kedua. Siklus pertama terjadi peningkatan menjadi $60,01 \%$ dan siklus kedua mencapai $78,50 \%$, sehingga dapat disimpulkan penerapan metode resitasi pada mata kuliah Menyimak Komprehensif dan Kritis dinyatakan dapat meningkatkan keterampilan menyimak mahasiswa.
\end{abstract}

Kata Kunci: menyimak, komprehensif, kritis, resitasi.

\begin{abstract}
This research based on students' difficulties in comprehension and critical listening ability. This research aimend to improve comprehension and critical listening ability using recitation method. The method of the research is classroom action research. The research subjects were class A students in semester 2 of the 2017. Data collection techniques used were direct communication, indirect communication, observation, measurement, and documentation. Data collection tools used were interview guides, questionnaires, observation guides, tests, and documentation. Data analysis techniques used comparative descriptive statistical techniques and critical analysis. The results showed a significant increase between the first and second cycles. The first cycle reached to $60.01 \%$ and the second cycle reached $78.50 \%$, it can be concluded that the implementation of the recitation method in a comprehension and critical listening ability subject can improve student listening skills.
\end{abstract}

Keywords: listening, comprehension, critical, recitation

\section{PENDAHULUAN}

Mahasiswa tidak bisa lepas dari interaksi dan komunikasi baik dengan sesama mahasiswa, dosen, keluarga, dan masyarakat. Proses interaksi dan komunikasi diperlukan keterampilan berbahasa aktif, kreatif, produktif, dan 
resesif apresiatif yang mana salah satu unsurnya adalah keterampilan menyimak yang bertujuan untuk menangkap dan memahami pesan ide serta gagasan yang terdapat pada materi atau bahasa simakan. Karena seringkali dalam berinteraksi dan berkomunikasi mengalami kendala "kita (sebagai simakan) atau orang lain (sebagai penyimak) tidak dapat menangkap dengan baik pesan ide atau gagasan pada saat komunikasi berlangsung."

Manusia merupakan mahluk individual sekaligus mahluk sosial. Oleh karenanya, manusia harus bergaul dan berhubungan dengan manusia lain. Sebagai makhluk sosial, manusia sering memerlukan orang lain untuk memahami apa yang sedang dipikirkan, apa yang dirasakan, dan apa yang diinginkan. Pemahaman terhadap pikiran, kehendak, dan perasaan orang lain dapat dilakukan dengan menyimak. Dalam kaitan dengan kemampuan menyimak, mahasiswa harus mampu mengingat fakta-fakta sederhana, mampu menghubungkan serangkaian fakta dari pesan yang didengarnya, dan menafsirkan makna yang terkandung dalam pesan lisan yang didengarnya.

Tarigan (1997: 58) menyatakan bahwa menyimak bukan hanya sebatas mendengar (hearing) saja, tetapi memerlukan kegiatan lainnya yakni memahami (understanding) isi pembicaraan yang disampaikan oleh si pembicara. Lebih jauh lagi diharapkan dalam menafsirkan (interprenting) butir-butir pendapat yang disimaknya baik tersurat maupun tersirat. Kegiatan selanjutnya dalam proses menyimak adalah kegiatan mengevaluasi (evaluating). Pada kegiatan mengevaluasi, si penyimak menilai gagasan baik dari segi keunggulan maupun dari segi kelemahannya. Kegiatan akhir yakni menanggapi (responding). Pada kegiatan menanggapi, si penyimak menyebut, mencamkan, menyerap, serta menerima gagasan yang dikemukakan oleh si pembicara.

Menyimak merupakan salah satu keterampilan berbahasa yang penting dalam kehidupan sehari-hari. Setiap hari manusia mendengar orang berbicara, baik secara langsung maupun melalui media elektronik. Dalam pengertian sempit berarti manusia melakukan kegiatan menyimak yang mengacu pada proses mental. Pendengar menerima rangsangan bunyi dari pembicara, kemudian menyusun penafsirannya. Dalam pengertian yang lebih luas menyimak, tidak 
hanya mengerti dan membuat penafsiran tertentu akan tetapi berusaha untuk melakukan apa yang disimaknya.

Menyimak dengan tujuan pemahaman dan pemaknaan secara keseluruhan tergolong kepada menyimak komprehensif. Pada penelitian yang dilakukan, menyimak yang digunakan adalah menyimak komprehensif dan kritis. Mendengar untuk tujuan memahami disebut juga menyimak komprehensif. Seseorang dapat dikatakan sebagai penyimak komprehensif yang baik apabila mampu menerima, memperhatikan, dan memberikan makna dari pesan yang sedekat mungkin sama dengan pesan yang disampaikan oleh pembicara. Menyimak kritis adalah kegiatan menyimak yang berupaya mencari kesalahan atau kekeliruan bahkan juga untuk mencari kebaikan dan kebenaran dari ujaran seseorang (Tarigan, 1994: 42).

Proses belajar mengajar tidak hanya sekadar proses memberi pelajaran atau menerima pelajaran. Namun, terdapat proses penerimaan ilmu dari pendidikan kepada peserta didiknya. Untuk dapat terjadi proses transfer ilmu tersebut, maka perlu metode-metode untuk mencapai tujuan dari pembelajaran. Metode atau model pembelajaran dapat menjadikan proses belajar mengajar semakin efektif dan efisien. Menurut Sudjana (2005: 76) metode pembelajaran adalah cara yang dipergunakan guru dalam mengadakan hubungan dengan siswa pada saat berlangsungnya pengajaran. Pada penelitian yang dilakukan, peneliti memilih metode resitasi yang akan digunakan untuk meningkatkan keterampilan menyimak komprehensif dan kritis.

Metode resitasi merupakan metode pemberian tugas kepada mahasiswa di luar jadwal pelajaran yang pada akhirnya dipertanggungjawabkan kepada dosen yang mengampu mata kuliah menyimak. Metode resitasi satu diantara pilihan metode mengajar seorang dosen. Dosen memberikan sejumlah tes kepada mahasiswa untuk dikerjakan di luar jadwal mata kuliah. Pemberian tes biasanya dilakukan pada setiap kegiatan belajar di kelas, pada akhir setiap pertemuan atau akhir pertemuan di kelas. Pemberian tugas merupakan satu diantara alternatif untuk lebih menyempurnakan penyampaian tujuan pembelajaran khusus. Hal tersebut disebabkan oleh padatnya materi pelajaran yang harus disampaikan sementara waktu belajar sangat terbatas di dalam kelas. 
Purwanto (2002: 13) menyatakan bahwa metode resitasi berarti mengulangi atau mengucapkan kembali (sesuatu) yang dipelajari. Slameto (2010: 115) menyatakan bahwa metode resitasi adalah cara penyampaian bahan pelajaran dengan memberikan tugas kepada siswa untuk dikerjakan di luar jadwal sekolah dalam rentang waktu tertentu dan hasilnya harus dipertanggungjawabkan kepada guru.

Langkah-langkah yang ditempuh dalam pelaksanaan pembelajaran dengan metode resitasi yaitu (Sudirman, 1992: 145): Pertama, tugas yang diberikan harus jelas. Kedua, tempat dan lama waktu penyelesaian tugas harus jelas. Ketiga, tugas yang diberikan terlebih dahulu dijelaskan/diberikan petunjuk yang jelas agar mahasiswa yang belum mampu memahami tugas dan berupaya untuk menyelesaikannya. Keempat, dosen harus memberikan bimbingan utamanya kepada mahasiswa yang mengalami kesulitan belajar atau salah arah dalam mengerjakan tugas. Kelima, memberi dorongan terutama bagi mahasiswa yang terlambat atau kurang bergairah mengerjakan tugas.

Keterampilan mahasiswa dalam menyimak komprehensif dan kritis masih rendah. Kekurangberhasilan pembelajaran menyimak disebabkan oleh sistem pembelajaran yang masih terpusat pada dosen. Mahasiswa kurang diberi kesempatan untuk berlatih dan mengembangkan kreativitasnya. Mahasiswa terpola dalam pembelajaran yang pasif. Untuk mengatasi permasalahan tersebut, maka diperlukan formula yang dapat membangkitkan daya ingat mahasiswa terhadap apa yang didengar atau diterima dari bahan pelajaran yang diberikan oleh dosen dengan pemberian metode belajar yang tepat dan efektif.

Berdasarkan permasalahan yang telah dikemukakan, maka untuk mengatasi permasalahan tersebut peneliti melakukan penelitian tindakan kelas dengan menerapkan metode resitasi pada mahasiswa kelas A Sore semester 2 angkatan 2017.

\section{METODE}

Metode penelitian yang digunakan dalam penelitian adalah classroom action research. Data penelitian adalah tentang proses dan hasil pembelajaran 
mata kuliah Menyimak Komprehensif dan Kritis. Sumber data adalah mahasiswa. Lokasi penelitian di IKIP PGRI Pontianak. Teknik pengumpul data menggunakan komunikasi langsung, komunikasi tidak langsung, observasi, pengukuran, dan dokumentasi. Alat pengumpul data menggunakan pedoman wawancara, angket, panduan observasi, tes, dan dokumentasi. Teknik analisis data meggunakan teknik statistik deskriptif komparatif dan analisis kritis.

\section{HASIL DAN PEMBAHASAN}

Kegiatan yang dilakukan penelitia dalam penelitian yaitu prasiklus, Siklus I, dan Siklus II.

\section{Prasiklus}

Berdasarkan observasi awal yang dilakukan peneliti, diperoleh informasi bahwa pelaksanaan pembelajaran sebelum menggunakan metode resitasi belum baik. Proses pembelajaran Menyimak Komprehensif dan Kritis masih terpusat pada dosen sehingga proses pembelajaran terasa sangat monoton. Pemberian tugas juga belum maksimal karena kurangnya pengawasan terhadap hasil kinerja mahasiswa. Hasil praobservasi menunjukkan $40 \%$ mahasiswa yang tuntas atau mencapai nilai KKM yang ditentukan oleh dosen pengampu dengan jumlah ketuntasan klasikal 35\% (10 orang) dari 100\% (40 orang) mahasiswa. Hal tersebut menunjukkan bahwa perlu dilakukan perbaikan dengan penggunaan metode yang sesuai dengan tujuan dari keterampilan menyimak komprehensif dan kritis.

\section{Siklus I}

Metode yang digunakan oleh dosen dalam proses pembelajaran yang berlangsung di kelas adalah metode ceramah dan terkadang dicampur dengan metode yang lain seperti praktik dan pemberian tugas. Dosen juga jarang menggunakan media pembelajaran sehingga proses pembelajaran menjadi monoton dan berfokus pada dosen. Mahasiswa hanya merespon pertanyaan dosen apabila ditunjuk. Pada proses pembelajaran peran dosen masih mendominasi sehingga mahasiswa kurang mendapat kesempatan untuk lebih aktif dalam sebuah proses pembelajaran Menyimak Komprehensif dan Kritis. 
Mahasiswa kurang berminat dalam menyimak komprehensif dan kritis yang disampaikan dosen di kelas sehingga mengakibatkan kurang terlaksananya proses pembelajaran di kelas dengan baik. Oleh karenananya diperlukan upaya dosen dalam meningkatkan keterampilan menyimak sehingga proses pelaksanaan yang disajikan dapat terlaksana dengan serta mencapai tujuan pembelajaran yang diharapkan. Berdasarkan hasil pengamatan, dosen mulai terbiasa menggunakan metode resitasi. Hal tersebut tampak pada hasil kinerja mahasiswa yang mencapai $60,01 \%$. Peningkatan juga terlihat pada proses pembelajaran yaitu dosen memberikan bimbingan kepada mahasiswa dalam belajar dan diskusi kelompok, dosen memberikan arahan dalam mengerjakan tugas, membimbing mahasiswa dalam menyimpulkan selama proses pemberian tugas serta memberikan langkahlangkah dalam pelaksanaan tugas kepada mahasiswa.

Berdasarkan data yang diperoleh selama observasi siklus I, maka peneliti menemukan beberapa kelemahan sebagai berikut: (1) Sebagian mahasiswa masih mengalami kesulitan dalam proses pembelajaran menyimak komprehensif dan kritis dengan menggunakan metode resitasi. Hal teresebut terlihat dari hasil observasi 60,01\%; (2) Mahasiswa kurang termotivasi belajar, kurang berminat dalam belajar, serta belum terbiasa selama pelaksanaan proses belajar dengan metode resitasi; (3) Dosen belum maksimal dalam penggunaan metode resitasi. Hal tersebut terlihat dari kurangnya pengawasan dari dosen pengampu mata kuliah sehingga masih ada mahasiswa yang melakukan penipuan. Mahasiswa hanya meniru hasil pekerjaan orang lain tanpa mau mengerjakan sendiri. Terkadang tugas dikerjakan oleh orang lain tanpa pengawasan dan sukar memberikan tugas yang memenuhi perbedaan individu; dan (4) Dosen sering memberikan tugas yang monoton (tidak bervariasi).

Berdasarkan kelemahan yang diperoleh selama penelitian, peneliti memberikan solusi cara untuk mengatasi kelemahan sebagai berikut: (1) Tugas yang diberikan kepada mahasiswa jelas, sehingga mahasiswa dapat mengetahui dengan jelas apa yang harus dikerjakan; (2) Tugas yang diberikan kepada mahasiswa dengan memperlihatkan perbedaan individu masing-masing; (3) Waktu untuk menyelesaikan tugas harus cukup; (4) Kontrol atau pengawasan 
yang sistematis atas tugas yang diberikan sehingga mendorong mahasiswa untuk belajar dengan sungguh-sungguh; (5) Tugas yang diberikan mempertimbangkan minat mahasiswa, bersifat praktis, dan ilmiah; dan (6) Memberikan pengakuan atau penghargaan terhadap hasil kerja mahasiswa.

Keterampilan menyimak komprehensif dan kritis pada mahasiswa setelah diterapkan metode resitasi dapat dijelaskan sebagai berikut: (1) Persentase yang diperoleh dalam menyimak komprehensif dan kritis sebesar 60,01\%; (2) Nilai yang diperoleh untuk tahap-tahap menyimak sebesar 55,02; (3) Persentase penerimaan, perhatian, dan pemberian makna dari pesan yang disampaikan sebesar 62,05\%; dan (4) Persentase proses penafsiran dalam mencari kesalahan atau kekeliruan bahkan mencari kebenaran atau kebaikan dari ujaran seseorang sebesar $63 \%$.

\section{Siklus II}

Pelaksanaan siklus II dengan metode resitasi sudah dilaksanakan dengan baik dan maksimal serta hasil belajar yang diperoleh mencapai ketentuan target KKM 75 dengan ketuntasan klasikal 78,50\%. Hal tersebut menunjukkan peningkatan yang sangat signifikan sehingga penelitian dinyatakan selesai. Tujuan menyimak komprehensif dan kritis tercapai dengan indikator pemahaman dan pemaknaan secara keseluruhan, mendengar untuk tujuan memahami, mampu menerima, memperhatikan, dan memberikan makna dari pesan yang sedekat mungkin sama dengan pesan yang disampaikan oleh pembicara.

Dosen melaksanakan proses pembelajaran sudah sesuai dengan rencana pelaksanaan pembelajaran dan menyelesaikan proses pembelajaran sesuai dengan waktu yang telah ditetapkan. Dosen terlihat lebih rileks dalam penyampaian materi dan jelas dalam pemberian tugas sesuai dengan saran dari peneliti.

Keterampilan menyimak komprehensif dan kritis pada mahasiswa setelah diterapkan metode resitasi dapat dijelaskan sebagai berikut: (1) Persentase tujuan menyimak komprehensif dan kritis meningkat menjadi 70,01\%; (2) Nilai tahaptahap menyimak nilainya meningkat menjadi 77,02; (3) Persentase penerimaan, perhatian, dan pemberian makna dari pesan yang disampaikan meningkat menjadi 75,05\%; dan (4) Persentase proses penafsiran dalam mencari kesalahan atau 
kekeliruan bahkan mencari kebenaran atau kebaikan dari ujaran seseorang meningkat menjadi $78,56 \%$.

Terjadi peningkatan sebesar 18\% dari siklus I ke siklus ke II. Pada siklus II dosen telah menerapkan metode resitasi dengan seksama, sehingga pembelajaran Menyimak Komprehensif dan Kritis pada mahasiswa telah berkembang dengan baik. Hal tersebut didukung hasil kinerja mahasiswa. Peningkatan yang signifikan mencapai target KKM 75 dari 75\% mahasiswa. Sehingga penelitian dinyatakan selesai dan berhasil. Hal tersebut sesuai dengan hasil penelitian Rivasintha (2015: 1) yang menunjukkan bahwa implementasi metode resitasi dalam pembelajaran sejarah Islamisasi dengan objek Keraton Kadriah dilaksanakan secara bertahap mulai dari persiapan, pelaksanaan, evaluasi dan tindak lanjut, pembelajaran sejarah Islamisasi dengan memanfaatkan Keraton Kadriah sebagai sumber sejarah dapat terwujud sehingga tujuan untuk meningkatkan kualitas dan mutu pembelajaran sejarah dapat tercapai sesuai yang diharapkan.

\section{SIMPULAN}

Berdasarkan hasil penelitian, maka dapat disimpulkan: (1) Dosen telah menerapkan metode resitasi terhadap keterampilan Menyimak Komprehensif dan Kritis pada mahasiswa dengan baik; dan (2) Keterampilan menyimak komprehensif dan kritis dengan metode resitasi pada mahasiswa pada prasiklus sebesar 35\%, siklus I sebesar 60,01\%, dan siklus II meningkat menjadi 78,56\%.

\section{DAFTAR PUSTAKA}

Iskandar. 2012. Peneltian Tindakan Kelas. Jakarta: Referensi.

Tarigan, H. G. 1997. Keterampilan Menyimak. Modul 1-5 Departemen Pendidikan dan Kebudayaan.

Tarigan, H. G. 1994. Menyimak: Sebagai Suatu Keterampilan Berbahasa. Bandung: Aksara.

Rivasintha, E. 2015. Pelajaran Sejarah Islamisasi melalui Metode Resitasi dengan Objek "Keraton Kadriah Pontianak". Sosial Horizon: Jurnal Pendidikan Sosial, 2(1): 1-13. 
Slameto. 2010. Belajar dan Faktor-faktor yang Mempengaruhi. Jakarta: Rineka Cipta.

Sudirman, A. M. 1992. Interaksi dan Motivasi Belajar Mengajar. Jakarta: Raja Grafindo Persada.

Sudjana, N. 2005. Metode Penelitian Pendidikan Pendekatan KuantitatifKualitatif dan $R \& D$. Bandung: PT Remaja Rosdakarya. 